\title{
How carnivorous fungi use three-celled constricting rings to trap nematodes
}

\author{
Keke Liu, Jianqing Tian, Meichun Xiang, Xingzhong Liu ${ }^{\bowtie}$ \\ State Key Laboratory of Mycology, Institute of Microbiology, Chinese Academy of Sciences, Beijing 100101, China \\ $\triangle$ Correspondence: liuxz@im.ac.cn \\ Received February 9, 2012 Accepted February 12, 2012
}

\begin{abstract}
Predacious fungi form specialized hyphae structures to trap nematodes and other microscopic animals. Among the six kinds of trapping devices, the constricting ring is the only one that actively captures nematodes. When a nematode enters the aperture of the ring, which is formed by three cells, the cells rapidly triple their volume, close the aperture and hold the nematode in place. Hyphae then penetrate and consume the nematode. This paper reviews the data and hypotheses on conserving the evolution of constricting rings and their cytological and molecular mechanisms.
\end{abstract}

\section{KEYWORDS constricting ring, predatory, mechanism}

\section{INTRODUCTION}

From the perspective of most humans, fungi in the form of edible mushrooms represent a wonderful food. As we eat a savory mushroom dish, we are pleased that fungi can greatly enhance our meals. Most of the mushrooms that we love to eat are produced by saprophytic fungi, i.e. fungi that obtain their carbon, energy, and nutrients from nonliving, organic substrates like decomposed tree stumps and leaf litter. These fungi do not present any obvious threat to humans or other animals (unless we consume one that contains toxins). Other fungi, however, turn the tables and capture and consume animals, albeit small ones like nematodes amoebas, rotifers, and even collembola (Duddington, 1955). These predacious, nematode-trapping fungi are the subject of this review.

Most of the nematode-trapping fungi belong to the Orbiliaceae in Ascomycota, but they have usually been described in their anamorphic stage (Liu and Xiang, 2009). The nematode-trapping fungi are ecologically united by their unusual ability to prey on and consume nematodes and other microscopic animals (Pramer, 1964).

Research on nematode-trapping fungi began in the first half of the $19^{\text {th }}$ century. The first described genus was $\mathrm{Ar}$ throbotrys (Corda, 1839) and the first described species was Arthrobotrys oligospora (Fresenius, 1852), but neither of these early reports recognized the predacious nature of the described fungi. Zorf (1888) was the first to report that $A$. olispora produced adhesive networks that captured nematodes.

Nematode-trapping fungi are not obligate predators, and they typically grow as saprophytes in pure culture. When nematodes are added to pure culture, however, the hyphae begin to produce trapping structures within $24 \mathrm{~h}$, i.e. the presence of prey causes the fungus to undergo the morphological changes that are required for predation (Pramer, 1964). Six sophisticated trapping devices have been described, and these include constricting rings, adhesive nets, adhesive columns, stalked adhesive knobs, unstalked adhesive knobs, and non-constricting rings (Drechsler, 1937; Barron, 1977; Stirling, 1991). Among these, constricting rings are perhaps the most interesting because they actively capture prey.

Constricting rings were described by Drechsler (1937). Each ring consists of three curved cells, one of which is connected to the parent hyphae by a two-celled stalk (Fig. 1A). The rings are developed at intervals along the parent hypha, and the stalk ensures that the rings are raised above and perpendicular to the fungal filament; this positioning increases the probability that a passing nematode will swim through the ring. The outer diameter of the ring is about 30 $\mu \mathrm{m}$, and the aperture diameter is about $20 \mu \mathrm{m}$. When a nematode enters the ring and contacts the inner surfaces of the ring cells, the three ring cells rapidly triple their volume within $0.1 \mathrm{~s}$ and fill the space previously occupied by the aperture (Fig. 1B) (Muller, 1958). The nematode is captured by 
A
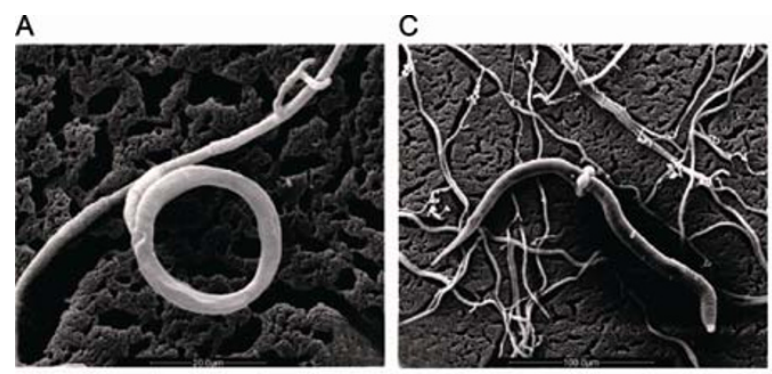

B
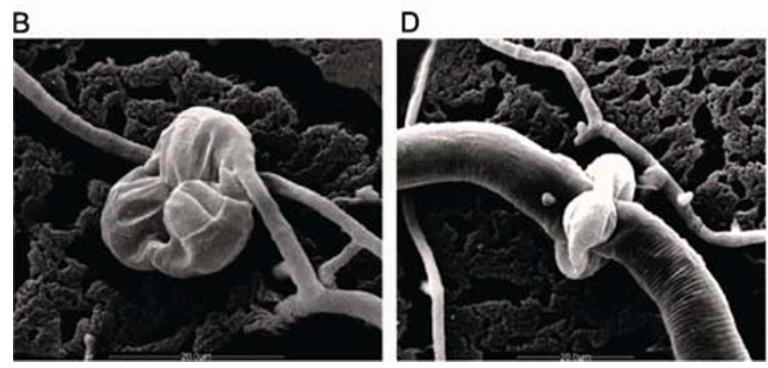

Figure 1. Morphology of constricting ring (CR). (A) A constricting ring; (B) Inflated constricting ring cells; (C-D) Nematode captured by a constricting ring.

occlusion and is penetrated by hyphae that grow from the surface of the ring cells in contact with the nematode (Fig. 1C-1D). The nematode soon dies as assimilatory hyphae spread and consume the prey's body contents. A constricting ring resembles a mouse trap; in both cases, a stationary trap springs shut when an animal activates a switch. In the case of constricting rings, the switch involves nematode contact with the inner surfaces of the ring cells.

\section{WHY DO FUNGI TRAP NEMATODES?}

As noted earlier, most fungi live as saprophytes, i.e. they obtain their carbon, energy, and nitrogen from nonliving substrates in the environment. In decomposed litter and wood on or in the soil, however, carbon is relatively abundant but nitrogen is relatively scarce. One solution for obtaining the limited supply of nitrogen is to capture and consume animals that are abundant in soil and other environments where decomposed organic matter is plentiful (Barron, 2003). Like other animals, nematodes are a rich source of nitrogen. Various authors have proposed that predatory fungi evolved from nonpredatory, cellulolytic or lignin-degrading fungi in nitrogen limited habitats (Dixon, 1952; Barron, 1969, 1992; Rubner, 1996). Multigene analysis has recently revealed a pattern for the evolution of the trapping structures of nematode-trapping fungi. Based on two fossil records and molecular clock calibration, fungal carnivorism diverged from saprophytism about 248.1 million years ago (Mya), shortly after the occurrence of the Permian-Triassic extinction event about 251.4 Mya. Active carnivorism (fungi with constricting rings) and passive carnivorism (fungi with adhesive traps) are distinct trapping mechanisms (Yang et al., 2007) that diverged from each other about 197.3 Mya, shortly after the occurrence of the Triassic-Jurassic extinction event about 201.4 Mya. The temporal correlation of the origin and evolution of fungal carnivorism in Ascomycota with major extinction events suggests that the presumably carbon-rich, nitrogen-poor environments created by mass extinctions might have been selected for fungi with the ability to capture and consume microscopic animals (unpublished data)

\section{MORPHOGENESIS OF CONSTRICTING RINGS}

Because the induction of trapping devices generally depends on the presence of nematodes (Pramer, 1964), early researchers suspected that some substance produced by nematodes functioned as a signal that switched on the predatory life style of nematode-trapping fungi. In 1959, Pramer and Stoll successfully induced Arthrobotrys conoides to form traps in pure culture by adding the nematode Neoaplectana glaseri or by adding nematode extract. The unknown substance that induced the development of trapping devices was termed "nemin" (Pramer and Stoll, 1959). In an attempt to identify nemin, Pramer (1964) determined that purified nematode proteins, whether they were treated or not treated with pepsin, induced trap formation. He also determined that subjecting nematode extract to enzymatic hydrolysis followed by dialysis reduced its activity. Pramer further tested 62 peptides, 27 amino acids, various blood fractions, animal hormones, and peptide antibiotics but none of these induced traps (Pramer, 1964). Valine was subsequently determined to have high trap-induction activity (Wootton and Pramer, 1966).

Besides nemin, traps can be induced by environmental and nutritional factors. Limited nutrition is essential for trap induction (Nordbring-Hertz, 1968), and some fungi form traps when they are transferred from a nutrient-rich medium to a nutrient-poor medium (Balan and Lechevalier, 1972).

Traps are usually produced from hyphae but can also be produced by germinating conidia, especially in the case of fungi that produce constricting rings (Persmark and Nordbring-Hertz, 1997). The production of traps by germinating conidia presumably minimizes the resources and time required by the fungus to begin to compete for nitrogen (Dackman and Nordbring-Hertz, 1992).

Time lapse cinephotomicrography has been used to record the morphogenesis of Arthrobotrys dactyloides constricting rings (Higgins and Pramer, 1967). When morphogenesis begins, hyphale branches destined to differentiate into constricting rings are highly refractile and robust. As these branches elongate, they arch and become hook like. The tip of the branch, which now consists of five cells, then fuses with the second cell of the branch, forming a three-celled ring that is connected to the parent hypha by a 
two-celled stalk. Each of the three cells that form the ring then increases to its final size (5-8 $\mu \mathrm{m}$ in width and $20-28 \mu \mathrm{m}$ in length).

After a constricting ring forms, it remains inactive until a nematode moves into the aperture. Like the leaves of sensitive plant, Mimosa pudica, and the leaves of Venus flytrap, Dionaea muscipula, the inner surfaces of ring cells respond to touch or pressure. This rapid response of plants and fungi to touch or vibration is termed thigmonasty (Jaffe et al., 2002).

A variety of stimuli other than nematodes can cause the ring cells to inflate. These other stimuli include hot water, dry heat, contact with fine needles, pressure, an increase of intracellular $\mathrm{Ca}^{2+}$, and electricity (Couch, 1937; Chen et al., 2001). Once a nematode is captured, it is rapidly assimilated by the fungus.

\section{CYTOLOGY OF CONSTRICTING RINGS}

As noted earlier, the constricting rings close and capture nematodes as a consequence of ring cell inflation. Researchers have proposed several mechanisms to explain the rapid inflation of ring cells in response to contact with nematodes. Couch (1937) suggested that the cells may have a high osmotic pressure and that cell membrane permeability is increased when the cells are touched; an increase in permeability would cause a rapid influx of water followed by cell inflation. Tzean and Estey (1979) suggested that air might substitute for water. Barron (1981) provided complementary information that explained how the cell walls could accommodate the rapid and large increase in cell volume. Ultrastructural examination revealed that the cell walls that line the aperture contain additional cell walls that are folded within the cells and that are nonfunctional until the trap is sprung. When the nematode touches the existing cell wall, the existing cell wall ruptures outward and the folded cell wall balloons out and forms the new wall of the now inflated cell. Accordingly, cell inflation does not require expansion of the existing cell wall or synthesis of a new cell wall but instead involves the replacement of the existing cell wall with a preformed cell wall that enables expansion; the deployment of the new cell wall is presumably associated with a change in cell permeability to water.

Unlike cells of vegetative hyphae, constricting ring cells have electron dense microbodies (EDM). EDM contain catalase and D-aminoacid oxidase before the prey has been penetrated but not after penetration has been completed (Veenhuis, 1984, 1985, 1989b). These observations indicate that EDM participate in the penetration of nematodes.

The aperture-side cell wall of constricting ring cells is complex. It contains an outer fibrillar layer, an electron lucent layer, a middle fibrillar layer, and an inner fibrillar layer.

After penetration, hyphae of nematode-trapping fungi spread throughout the nematode cadaver, digesting the nematode and assimilating the nutrients. The hyphae growing in nematodes contain lipid droplets that presumably contain materials that have been obtained from the prey and that are being stored to support future fungal growth and activity (Veenhuis, 1989a).

\section{MOLECULAR PROCESS UNDERLYING CONSTRICTING RING FUNCTION}

All cells that can respond to environmental stimuli require a signal transduction pathway that perceives and transfers the signal from the environment to the cell. In 2001, a signal transduction pathway essential for ring cell inflation and containing a G-protein-coupled receptor was described by Chen et al. (2001). The latter authors reported that a G-protein activator stimulated the inflation of ring cells, whereas a G-protein inhibitor blocked inflation. An increase in the concentration of intracellular $\mathrm{Ca}^{2+}$ was also necessary for ring cell inflation. Based on their findings, Chen et al. proposed that pressure exerted by a nematode activates heterotrimeric G-proteins in the ring cells. The activation leads to an increase in the concentration of cytoplasmic $\mathrm{Ca}^{2+}$, activation of calmodulin, and the opening of water channels. As water enters the cell, the cell expands. The expansion would presumably be facilitated by the preformed cell wall as described by Barron (1981).

\section{CONCLUDING REMARKS}

"Nematode-trapping fungi" appear to live both as saprophytes and predators. Although they seem to be mainly saprophytic, they can increase their access to nitrogen and other nutrients when these are limited by producing traps that capture nematodes and other small animals. Among the trapping devices, the constricting ring is perhaps the most sophisticated and interesting. Phylogenetic analysis suggests that nematode-trapping fungi may have developed predatory ability in response to mass extinction events, which resulted in carbon-rich, nitrogen-poor environments. According to this hypothesis, competition for nitrogen in carbon rich environment is selected for predatious ability in some species.

Although researchers have long proposed that an unknown biochemical, termed nemin, was responsible for ring induction, nemin remains to be identified. With respect to ring function, fungi that produce constricting rings are similar to many plants and other fungi in that they are able to sense pressure, i.e. they exhibit thigmonasty. When a nematode enters a constricting ring and generates pressure along the cell walls that line the aperture, the ring cells rapidly inflate and immobilize the nematode.

Recent research suggests that touch or pressure triggers a signal transduction pathway in which G-protein is an important component. 


\section{REFERENCES}

Balan, J., and Lechevalier, H.A. (1972). The predaceous fungus Arthrobotrys dactyloides: induction of trap formation. Mycologia 64, 919-922.

Barron, G.L. (1969). Isolation and maintenance of endoparasitic nematophagous Hyphomycetes. Can J Bot 47, 1899-1902.

Barron, G.L. (1977). The nematode-destroying fungi. Canada: Canadian Biological Publications.

Barron, G.L. (1981). Predators and parasites of microscopic animals. Biology of Conidial Fungi. Vol. 2. Cole GT and Kendrick B, eds. New York: Academic Press. 167-200.

Barron, G.L. (1992). Lignolytic and cellulolytic fungi as predators and parasites. The fungal community: its organization and role in ecosystem. Carroll GC, and Wicklow DT, eds. New York: Marcel Dekker. 311-326.

Barron, G.L. (2003). Predatory fungi, wood decay, and the carbon cycle. Biodiversity 4, 3-9.

Chen, T.H., Hsu, C.S., Tsai, P.J., Ho, Y.F., Lin, N.S., and Lin, N.S. (2001). Heterotrimeric G-protein and signal transduction in the nematode-trapping fungus Arthrobotrys dactyloides. Planta 212, 858-863.

Corda, A.C.J. (1839). Pracht-Flora europäischer Schimmelbildungen. Leipzig, Germany.

Couch, J.M. (1937). The formation and operation of the traps in the nematode catching fungus Dactylella bembicoides Drechsler. Elisha Mith Sci Soc 53, 301-309.

Dackman, C., and Nordbring-Hertz, B. (1992). Conidial traps-a new survival structure of the nematode-trapping fungus Arthrobotrys oligospora. Mycol Res 96, 194-198.

Dixon, S.M. (1952). Predacious fungi from the rotten wood. Trans $\mathrm{Br}$ Mycol Soc 35, 144-148.

Drechsler, C. (1937). Some hyphomycetes that prey on free-living terricolous nematodes. Mycologia 29, 447-552.

Duddington, C.L. (1955). Fungi that attack microscopic animals. Bot Rev 21, 377-439.

Fresenius, G. (1852). Beitrage zur Mykologie 1-2, 1-80.

Higgins, M.L., and Pramer, D. (1967). Fungal morphogenesis: ring formation and closure by Arthrobotrys dactyloides. Science 155, 345-346.

Jaffe, M.J., Leopold, A.C., and Staples, R.C. (2002). Thigmo responses in plants and fungi. Am J Bot 89, 375-382.
Liu, X.Z., and Xiang, M.C. (2009). The living strategy of nematophagous fungi. Micoscience $50,20-25$.

Muller, H.G. (1958). The constricting ring mechanism of two predacious Hyphomycetes. Trans Br Mycol Soc 41, 341-364.

Nordbring-Hertz, B. (1968). The influence of medium composition and addition of animal origin on the formation of capture organs in Arthrobotrys oligospora. Physiol Plant 21, 52-65.

Persmark, L., and Nordbring-Hertz, B. (1997). Conidial trap formation of nematode-trapping fungi in soil and soil extracts. FEMS Microbiol Ecol 22, 313-323.

Pramer, D. (1964). Nematode-trapping fungi. Science 144, 382-388.

Pramer, D., and Stoll, N.R. (1959). Nemin: a morphogenic substance causing trap formation by predaceous fungi. Science 129 , 966-967.

Rubner, A. (1996). Revision of predacious hyphomycetes in the Dactylella-Monacrosporium complex. Stud Mycol 39, 1-134.

Stirling, G.R. (1991). Biological control of plant parasitic nematodes: progress, problems and prospects. Wallingford, UK: CAB International. 56-59.

Tzean, S.S., and Estey, R.H. (1979). Transmission electron microscopy of fungal nematode-trapping devices. Can J PI Sci 59, 785-795.

Veenhuis, M. (1984). Occurrence, characterization and development of two different types of microbodies in the nematophaous fungus Arthrobotrys oligospora. FEMS Microbiol Lett 24, 31-38.

Veenhuis, M. (1985). Development and fate of electron dense microbodies in trap cells of the nematophagous fungus Arthrobotrys oligospora. Ant Van Leeuw 51, 399-407.

Veenhuis, M. (1989a). An improved method for light-and electron microscopical studies of nematode/fungal interactions. Ant Van Leeuw 55, 361-368.

Veenhuis, M. (1989b). Significance of electron dense microbodies in trap cells of the nematophagous fungus Arthrobotrys oligospora. Ant Van Leeuw 56, 251-261.

Wootton, L.M.O. and Pramer, D. (1966). Valine-induced morphogenesis in Arthrobotrys conoides. Bacteriol Proc 75, 225-232.

Yang, Y., Yang, E.C., An, Z.Q., and Liu, X. (2007). Evolution of nematode-trapping cells of predatory fungi of the Orbiliaceae based on evidence from rRNA-encoding DNA and multiprotein sequences. Proc Natl Acad Sci U S A 104, 8379-8384.

Zorf, W. (1888). Zur kenntnis der infektions krandheiten nerderer thiere und pfanzen. Nova Acta Acad leop Carol 52, 314-337. 